\title{
Exploring gender and disability stereotypes in the courtroom: A case example
}

\author{
Maretha de Waal
}

\begin{abstract}
MARETHA DE WAAL holds a DLitt et Phil degree in Sociology. She specialises in the fields of gender, disability and ethics. She is located at the Department of Nursing Science at the University of Pretoria. Email: marethadewaal@gmail.com
\end{abstract}

\begin{abstract}
The United Nations Convention on the Rights of Persons with Disabilities (CRPD) and its Optional Protocol obliges member states to recognise the human rights of persons with disabilities in all spheres of society, including the administration of justice. This article turns its gaze to the administration of justice as required by the CRPD against the backdrop of a steady stream of gender and its disability stereotypes that dominated public discourse during the trial of Oscar Pistorius, the case selected for analysis. In phase 1 of the study an applied thematic analysis was conducted on media reports on the trial of Oscar Pistorius. The analysis revealed the different ways in which the prosecutor and the defence used gender and disability stereotypes to build their respective cases on the charges against Pistorius. In phase 2 of the study, applied thematic analysis was used to explore whether prejudicial presumptions based on the stereotypes used by counsel found their way into the final judgment. The results of the study have implications for further research on the administration of justice that involves persons with disabilities.
\end{abstract}

\section{Keywords}

prejudicial presumptions, access to justice, disability rights, reasonable accommodation

\section{Introduction}

"I've made a terrible mistake, my lady." These were the words of Oscar Pistorius during the lengthy trial that ensued after the killing of his girlfriend, Reeva Steenkamp, on Valentine's Day 2013. Pistorius was charged with premeditated murder together with other charges related to discharging of a firearm in a public space and possession of unlicensed ammunition. For 49 days of the trial gender and disability stereotypes covered the pages of newspapers and dominated public discourse.

Significantly, just after the start of the trial on the eve of International Women's Day, the United Nations (UN) High Commissioner for Human Rights, Judge Navi Pillay, released a statement on the influence of harmful gender stereotypes in judges' interpretation of the law and handing down of decisions (Pillay, 2014). She reminded member states of the UN of their obligation to take measures to eliminate wrongful gender stereotyping in all aspects of the criminal justice system, including investigation, prosecution, judgment and sentencing, and concluded as follows (Pillay, 2014): 
If we are serious about achieving gender equality, well into the $21^{\text {st }}$ century, we must devote more energy to dismantling prejudicial presumptions about women and men ... We must see them for who they are - human beings in all their diversity. This is the demand of equality, which is the foundation of human rights law ... It is my sincere hope that work on this critical issue will begin in the place that most symbolises justice: the courtroom.

This statement could not be more timeous, because as the Pistorius trial got under way stereotypes directly and indirectly associated with Pistorius' disability came to the fore. Phrases such as "from hero to zero", and to make a "descent from a sporting god to personal hell" (Smith, 2014:16) created research interest and prompted the researcher to monitor and analyse media reports for prejudicial presumptions that could influence the process and outcome of the trial.

The following research questions guided the study: What were the predominant gender and disability stereotypes that emerged in the courtroom?; and How were these prejudicial presumptions addressed in the final judgment?

\title{
Rationale for the study
}

South Africa is a member of the UN and ratified the UN Convention on the Rights of Persons with Disabilities (CRPD) and its Optional Protocol in 2007. The Preamble of the CRPD expressly emphasises the need to "incorporate a gender perspective in all efforts to promote the full enjoyment of human rights and fundamental freedoms by persons with disabilities". Article 8 further states the need:

to foster respect for the rights and dignity of persons with disabilities and to combat stereotypes, prejudices and harmful practices relating to persons with disabilities, including those based on sex and age, in all areas of life.

The CRPD requires states to report to the CRPD Committee on progress in implementation of this Convention and to report and cite examples of such implementation or failure to implement. Given the worldwide following of the Oscar Pistorius trial, South Africa may well be questioned if the next country report to the CRPD Committee does not contain details of this case.

This study is intended to contribute to analysis of the implementation of disability rights in South Africa, using the CRPD as the guiding instrument.

\begin{abstract}
About the case
Oscar Pistorius, a double amputee, won gold medals at the 2012 Summer Paralympics for the men's 400 metre race and in the 4 x 100 metre relay, setting world records in both events. He also took a silver Medal in the 200 metre race, having set a world record in the semi-final.

The media image of Pistorius, until the shooting of his girlfriend, was one of a 'hero' who 'transcended' disability to being super-able. Pistorius once declared to a journalist "I don't see myself as disabled" (Jeré Longman, 'An amputee sprinter: Is he disabled or too abled?', www.nytimes.com/2007/05/15/sports/othersports/15runner.html?hp, May 15, 2007) Instead he seemed to have embraced the metaphor of his body as partly mechanical. He titled his autobiography Blade Runner, a science fiction reference, and posed for advertising
\end{abstract}


campaigns centred on his image as part-man, part-machine - most notoriously Nike's "I am the bullet in the chamber" (Figure 1).

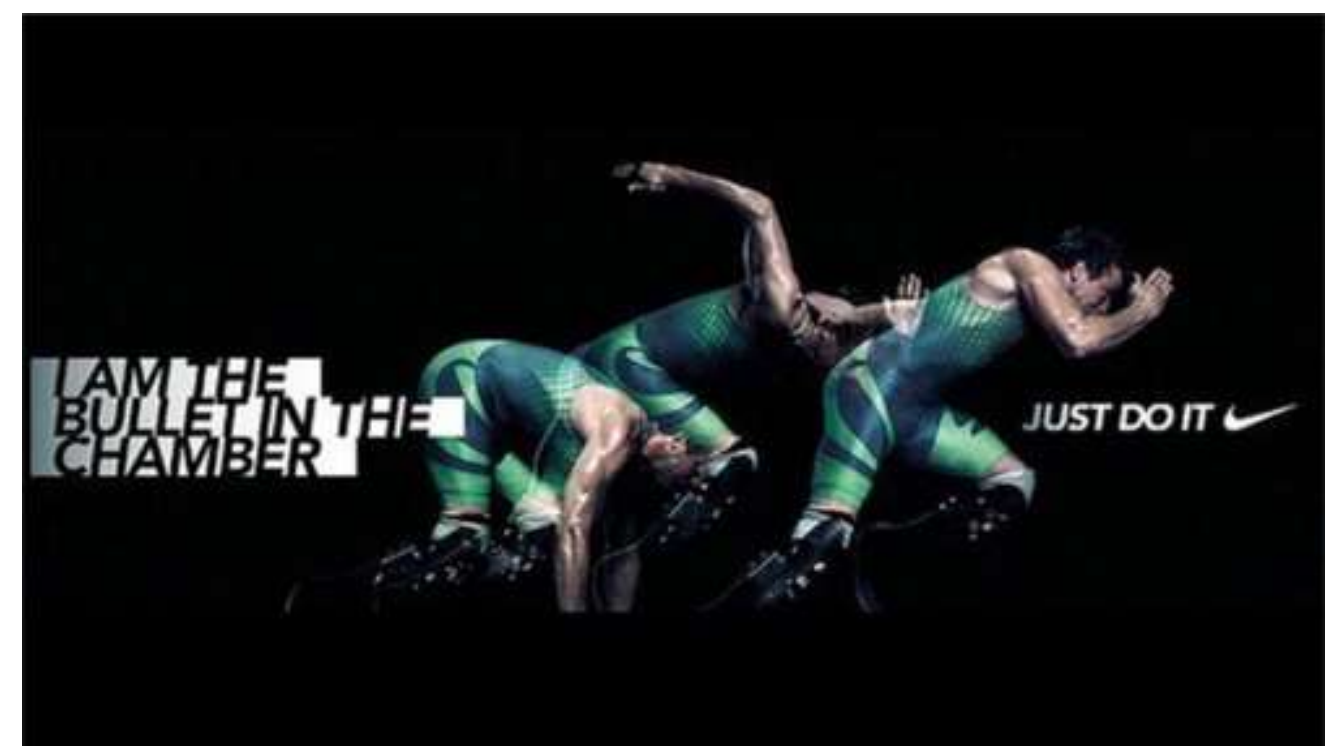

Figure 1. This Nike advert featuring Pistorius was pulled from his website following his arrest.

Four charges were brought against Pistorius, relating to premeditated murder, possession of ammunition without a licence, and two charges of unlawful discharging of a firearm. Pistorius was found guilty on charges of culpable homicide and discharging of a firearm in a public space, for which he was sentenced to 5 years' imprisonment on the first charge and 3 years' imprisonment on the second charge. The 49 days of the trial were covered extensively in the national, international and social media. The State has been granted leave to appeal against the verdict.

\section{Conceptual framework}

Section 34 of the Bill of Rights in the Constitution of South Africa, Act 108 of 1996, provides for fairness in public hearings. Courts in South Africa are obliged to ensure that the proceedings before them are always fair (Currie and De Waal, 2005:732). South African criminal law recognises that "prejudicial presumptions contribute to substantial unfairness to the prosecution and are detrimental to the administration of justice" (Currie and De Waal, 2005:792).

For the purpose of this study, prejudicial presumptions are understood to be based on gender and disability stereotypes which may be used in positive or negative ways. Stereotypes can be harmful when the outcome of the use thereof contributes to discrimination against persons with disabilities and compromising disability rights, as conceptualised in the CRPD and South Africa's national legislation.

Section 9 of the Constitution (Act 108 of 1996) prohibits the State and any person from unfairly discriminating directly or indirectly against anyone on one or more grounds, including gender, sex and disability, and provides for special measures for redress or restitution to ensure fair treatment. 
The Promotion of Equality and Prevention of Unfair Discrimination Act 4 of 2000 (Equality Act) provides for the prevention and prohibition of unfair discrimination. Unfair, unlawful discrimination is defined in the Equality Act as:

any act or omission, including policies, legislation, rules and practices, or any situation which directly or indirectly 1) imposes burdens, obligations or disadvantages on any person; or 2) withholds benefits or opportunities from any person on one or more of the grounds of discrimination.

To understand what prejudicial presumptions entail, one needs to go back to the meaning of and link between stereotypes, prejudice and discrimination.

The term 'stereotype,' coined in 1798 by the French printer Didot, originally referred to a printing process used to create reproductions (Ashmore and Del Boca, 1981). Journalist Walter Lippmann (1922) later likened stereotypes to "pictures in the head" or mental reproductions of reality, and from there the term gradually came to mean generalisations -or, quite often, overgeneralisations - about the members of a group. As with prejudice, these generalisations can at times be positive, but for the most part they tend to be negative and resistant to change. Stereotypes are not only harmful in their own right, they do damage by fostering prejudice and discrimination.

Although social scientists often differ in the precise way they define 'prejudice', most agree that it involves a prejudgement, usually negative, about a group or its members (Nelson, 2009). As commonly used in psychology, prejudice is not merely a statement of opinion or belief but an attitude that includes feelings such as contempt, dislike or loathing, which then impact on how a person is treated or responded to or, in the case of a court, how the person is tried and the outcome of the trial.

For the purpose of this study it is therefore relevant to identify base stereotypes that may have had an influence on the process and outcome of the trial of Oscar Pistorius. In an overview of relevant literature, two important sets of literature were found: literature on ways in which men with physical disabilities construct their gender identity, and literature on the media images and portrayal of persons with disabilities that negate their disability. The key points that emanated from the literature are discussed below.

\section{Negotiating masculine gender identity and disability}

Lorber and Moore (2002) pointed out that gender is an achievement status, as gender reflects a person's self-representation and how society responds to a person's gender presentation. Accordingly, gender is not static and an individual has to work at it to maintain his or her status in society based on the prevailing norms for what is constructed as masculine or feminine. One's compliance to society's expectations is continuously evaluated, if not also challenged.

Yoder (2003:43-45) noted that the socially constructed norm of hegemonic masculinity put men constantly under pressure to "act like a man". This is also the case for persons with disabilities, who not only have to negotiate their disability status but also their gender status. This has specifically been noted in the case of men with physical disabilities (Murphy, 1990, in Gerschick and Miller, 1995:185): 
... for men with physical disabilities, masculine gender identity and practice are created and maintained at the crossroads of the demands of contemporary masculinity and the

stigmatization associated with disability.

Competitive sports have become, for boys and men as players and spectators, a way of constructing a masculine identity, a legitimate outlet for violence and aggression, and an avenue for upward mobility.

In his classic work The Portrayal of Self in Everyday Life, Ervin Goffman (1959) explained that people play their roles in society according to the role expectations of society at the time. In 'Stigma' he described how people convey or conceal 'social information' about themselves, particularly in relation to stigmatised individuals such as persons with disabilities - a process of constant identity management.

Having a disability and being 'masculine' are often in conflict, since a person with a disability is socially assumed to be helpless and dependent, whereas masculinity is associated with power and autonomy (Shuttleworth et al, 2012). This resonates with Murphy's (1990) conceptualisation of the 'embattled identities' of men with disabilities.

Gerschick and Miller (2000) built on Goffman's theory to develop a theory of disability and gender. Accordingly, many men disavow any aspect of the self that resembles a feminine trait in order to maintain socially accepted masculine identity.

Gerschick and Miller (2000:126-127) identified three dominant coping strategy ies of men with disabilities in relation to the "standards inherent in dominant masculinity": reformulation, reliance and rejection. Reformulation entails men's redefinition of hegemonic characteristics on their own terms; reliance entails adoption of selected predominant attributes; and rejection involves renunciation of these standards and the creation of one's own standards. Gerschick and Miller (2000) point out that these categories are fluid and men use selectively from all these categories in defining their sense of self.

\section{Negating disability}

People with disabilities are often perceived to be helpless and treated with pity (McDougall, 2006). Discourses of disability in the media reinforce the images of persons with disabilities as victims who require help, treatment or rehabilitation based on their "abnormality, impairment, illness, or a tragic loss of normal, healthy functioning" (Gold and Auslander, 1999, quoted by Stadler, 2006:373).

On the other hand, media images of 'supercrips' are also prevalent. Supercrips, as described by, for example, Amit Kama (2004:447) constitute "examples of disabled individuals who can overcome difficulties and become 'normal' human beings." Kama (2004) identifies two supercrip prototypes in the media: the 'regular' disabled, who achieve mundane accomplishments, which because of their impairment are considered exceptionally successful; and people who achieve feats that even nondisabled persons rarely attempt, and who serve as role models and objects of emulation.

Silva and Howe (2012) caution against supercrip narratives that may have a negative impact on the physical and social development of disabled individuals, by reinforcing what they term "achievement syndrome" and pressuring persons with disabilities to overcome the constraints of their disability and to be successful in spite of their disability. 
Gill (2006:186) as well as Satz (2008) argue that people with disabilities are not innately vulnerable but are made so by a social environment that devalues human difference. Vulnerability may also vary according to different situations and capacities of diverse persons.

\section{Research design and methodology}

The qualitative research paradigm was selected for the study, utilising applied thematic analysis, which is a type of inductive analysis of qualitative data that can involve multiple analytical techniques for identifying, analysing and reporting patterns (themes) within data. It organises and describes data in (rich) detail as well as assisting in interpreting various aspects of the research topic (Braun and Clarke, 2006:79).

The process for applied thematic analysis as described by Braun and Clarke (2006) was followed to identify stereotypes used in the courtroom. In phase 1 of the study the online video and verbatim reports available on the News 24 website were monitored for the 49 days of the duration of the trial, to identify the gender and disability stereotypes used by the prosecution and the defence in the court proceedings. In phase 2 the published version of the judgment (The State v Oscar Leonard Carl Pistorius) was analysed to identify prejudicial presumptions.

The data analysis involved the following steps: 1) becoming familiar with the data by reading the print and electronic newspaper reports and selecting relevant reports; 2) analysing the selected reports and generating initial codes; 3) searching for themes by comprehensively looking at the codes; 4) reviewing themes to ensure applicability and distinctiveness; 5) defining and naming themes; and 6) producing the report.

\section{Results}

\section{Role of stereotypes in the Pistorius case}

Two sets of base stereotypes related to gender and disabilitywere identified. The base gender stereotypes that were identified related respectively to 'hegemonic masculinity' and 'atypical masculinity'. The base disability stereotypes that were identified were those of 'supercrip' and 'incapacity', as indicated in Table 1.

Table 1: Base stereotypes identified in the study

\begin{tabular}{|l|l|l|l|}
\hline & \multicolumn{2}{|c|}{ Gender stereotypes } \\
\hline \hline \multicolumn{2}{|l|}{} & Hegemonic masculinity & Atypical masculinity \\
\hline Disability stereotypes & Supercrip & \\
\hline \hline & Incapacity & \\
\hline
\end{tabular}

In analysing the use of stereotypes it became clear that both the prosecution and the defence relied on stereotypes to build their respective arguments. Table 2 shows the stereotypes invoked by the prosecution, while Table 3 shows the stereotypes invoked by the defence. 
Table 2: Stereotypes invoked by the prosecution

\begin{tabular}{|l|l|l|l|}
\hline \multicolumn{2}{|l|}{} & \multicolumn{2}{|c|}{ Gender stereotypes } \\
\hline \hline & Hegemonic masculinity & Atypical masculinity \\
\hline Disability stereotypes & Supercrip & Violence \\
\hline \hline & Incapacity & Expedience & \\
\hline
\end{tabular}

Table 3: Stereotypes invoked by the defence

\begin{tabular}{|l|l|l|l|}
\hline \multicolumn{2}{|l||}{} & Gender stereotypes & \\
\hline \hline \multicolumn{2}{|l|}{} & Hegemonic masculinity & Atypical masculinity \\
\hline Disability stereotypes & Supercrip & & Emotional \\
\hline \hline & Incapacity & & Vulnerable \\
\hline
\end{tabular}

Stereotypes invoked by the prosecution

The State Prosecutor relied heavily on the supercrip and hegemonic masculinity stereotypes by building its case on their constructions of Pistorius as a violent person who has a disregard for the safety of others. This included the charge of premeditated murder and countering arguments of vulnerability by ascribing these claims as expedience and exploitation of his disability (Table 2 refers).

The prosecutor went to great lengths to highlight the 'hero' image of Pistorius, thereby drawing on the hegemonic masculinity and supercrip stereotype. In crossexamination the State Prosecutor asked Pistorius: "You are a model for sportsmen, ablebodied and disabled, all over the world?", thereby invoking the masculine stereotype of strength, responsibility and ability. Then he demanded adherence to the social norm, drawing on the false positive hegemonic masculinity stereotype: "Why don't you take responsibility for that [you shot and killed Reeva Steenkamp]"? (Smith, quoting State Prosecutor Adv. Gerrie Nel, 2014:16). The Prosecutor responded harshly to Pistorius's display of emotions, indicating intolerance for atypical masculinity: "Why are you getting emotional now, when I ask the hard questions?"

Based on the above examples it can be deduced that the prosecution relied on the supercrip stereotype for its case and arguments.

Stereotypes invoked by the defence

Table 3 provides a summary of stereotypes invoked by the defence for Pistorius in support of its case.

The defence lawyer took pains to show that Pistorius is not all about 'Guns, girls and German cars' (caption used on cover of City Press newspaper, March 9, 2014). The Defence Advocate for Pistorius focused on Pistorius' non-stereotypical gender identity and expression by depicting him as loving, emotional and vulnerable. He went to great lengths to focus on his vulnerability, to the extent of almost emasculating Pistorius: "When anxious, he pitches his voice ... sounds like a woman" (Deborah Patta, 'Pistorius trial: What's coming up', City Press, March 9, 2014). 
Pistorius was often seen in the courtroom being deeply emotional. A defence witness stated: "Pistorius was an emotional wreck on the night he was found kneeling next to Steenkamp's body" (Werner Swart, 'Five big questions for Oscar', http://www.timeslive.co.za/local/2014/03/09/five-big-questions-for-oscar1, March 9, 2014).

Later, when the defence argued for consideration of the vulnerability of Pistorius as a person with a disability, the defence called on an expert witness, who testified: "You've got a paradox of an individual who is supremely able, and you've got an individual who is significantly disabled" (http://www.telegraph.co.uk/news/worldnews/oscarpistorius/10943575/The-paradox-of-Oscar-Pistorius-supremely-able-and-significantlydisabled.html).

In his own testimony on the stand Pistorius admitted to being "shy" and "embarrassed" by people seeing his prosthetic legs. The defence stressed the athlete's extremely limited and painful mobility without his prosthetic legs. In the report on Pistorius' mental evaluation it was reported that Pistorius suffers "extreme self-consciousness and anxiety about being ridiculed or embarrassed" (Davis, 2014).

\section{Comparing the use of stereotypes by the prosecution and the defence}

In summary, the defence team (including Pistorius himself) presented him as 'atypical' or different to the social norm for hegemonic masculinity. The disability stereotypes that emerged followed a pattern not dissimilar to that of gender stereotypes. While the defence invoked claims of atypical conduct and vulnerability, similar to the charity and medical models of disability, Pistorius was portrayed by the prosecution as a supercrip who negated his disability, as evidenced by his sports achievements, with the capacity to kill (Table 4 refers).

Table 4: Comparison of the use of stereotypes by the defence and the prosecution

\begin{tabular}{|c|c|c|c|}
\hline & & \multicolumn{2}{|c|}{ Gender stereotypes } \\
\hline & & Hegemonic masculinity & Atypical masculinity \\
\hline \multirow[t]{2}{*}{$\begin{array}{l}\text { Disability } \\
\text { stereotypes }\end{array}$} & Supercrip & $\begin{array}{l}\text { Stereotypes of hegemonic masculinity and } \\
\text { supercrip invoked by the prosecution in } \\
\text { support of its case of premeditated murder }\end{array}$ & $\begin{array}{l}\text { Stereotypes of atypical masculinity and } \\
\text { incapacity invoked by the defence in } \\
\text { support of its case of incapacity to kill }\end{array}$ \\
\hline & Incapacity & & \\
\hline
\end{tabular}

The results of phase 2 of the research, based on an applied thematic analysis of the judgment (The State V Oscar Leonard Carl Pistorius), are presented in the next section.

\section{Prejudicial presumptions in the judgment}

\section{Awareness of possible bias created by the media}

In her judgment, Judge Masipa responded specifically to the role of the media as an influence on witnesses. She foregrounded her judgment by the following statement, while simultaneously dissociating herself from the influence of the media on her own judgment in her application of the rule of law (Judgment, p. 3296): 
I continue to explain why most witnesses got their facts wrong. The fact that this case attracted much media attention, especially soon after the incident and the fact that it became a topic in many homes, also did not assist ... I am of the view that the probability is that some witnesses failed to separate what they knew personally, from what they had heard from other people or what they had gathered from the media.

Recognising the possible influence of the media on witnesses, the Judge stated emphatically her reliance on technology to obtain objective evidence (Judgment, p. 3298):

$\ldots$ this court is in a fortunate position in that it has objective evidence in the form of technology which is more reliable than human perception and human memory and against which all the other evidence can be tested.

The Judge referred here to forensic, telephone records and other scientific evidence.

\section{Vulnerability and reasonability}

Judge Masipa explained how she applied the measure of the reasonable person in the position of the accused to come to a conclusion on the arguments presented to the court on the vulnerability of Pistorius and the reasonableness of his actions: "It is also understandable, that a person with a disability such as that of the accused, would certainly feel vulnerable, when faced with danger ..." (Judgment, p. 3317).

Whilst acknowledging the vulnerability of persons with disabilities, she did not entertain this as a stereotype. Instead, she argued that various categories of people are vulnerable but would not resort to an armed response to a threat of danger (Judgment, $\mathrm{p}$. 3331):

... vulnerability is not unique as millions of people in this country can easily fit into that category... Women, children, the elderly and all those with limited mobility would fall under the same category, but would it be reasonable if without further ado, they armed themselves with a firearm when threatened with danger? I do not think so ...

There is no evidence of prejudicial assumptions in her application of the principle of the reasonable person, as illustrated by the following (Judgment, p. 3349):

A reasonable person therefore in the position of the accused, with similar disability would have foreseen that possibility, that whoever was behind the door might be killed by the shots and would have taken steps to avoid the consequences and the accused in this matter failed to take any step to avoid the resultant death.

\section{Disability rights}

As pointed out above, the Judge recognised the legal requirement of sentencing that is "fair and just to society and to the accused", also in view of the legal rights of persons with disabilities. Judge Masipa said (http://www.telegraph.co.uk/news/worldnews/oscarpistorius/11158043/Oscar-Pistorius-sentence-live.html):

Having regard to the circumstances of the latter, I am of the view that a non-custodial sentence would send the wrong message to the community. On the other hand, a long sentence would also not be appropriate either as it would lack the element of mercy. 
In ensuring non-discrimination against Pistorius, the Judge had to ensure that requirements for 'reasonable accommodation' as per the CRPD would be met. 'Reasonable accommodation' means necessary and appropriate modification and adjustments not imposing a disproportionate or undue burden, where needed in a particular case, to ensure to persons with disabilities the enjoyment or exercise on an equal basis with others of all human rights and fundamental freedoms (CRPD Article 2). The Judge said (http://www.telegraph.co.uk/news/worldnews/oscar-pistorius/11158043/Oscar-Pistoriussentence-live.html):

I am satisfied that prisons can accommodate prisoners with the accused's needs. I have no reason to believe the accused would present the Department of Correctional Services with an insurmountable problem.

This statement was based on evidence heard by the Acting National Commissioner of the Department of Correctional Services, who gave assurances that Pistorius would be held in a hospital section to cater for his specific needs.

Table 5 provides the summary of the judgment, with tentative links to the base stereotypes described earlier.

Table 5: Responsiveness to prejudicial presumptions in the judgment

\begin{tabular}{|c|c|c|c|}
\hline & & \multicolumn{2}{|l|}{ Gender stereotypes } \\
\hline & & Hegemonic masculinity & Atypical masculinity \\
\hline \multirow[t]{2}{*}{$\begin{array}{l}\text { Disability } \\
\text { stereotypes }\end{array}$} & Supercrip & $\begin{array}{l}\text { Count 2: Not guilty (discharging a firearm through the } \\
\text { sunroof of a car) Count 3: Guilty (discharging a firearm } \\
\text { in a public place) Count 4: Not guilty and discharged } \\
\text { (possession of ammunition without a licence) }\end{array}$ & $\begin{array}{l}\text { Count 1: Guilty of culpable } \\
\text { homicide (killing of another } \\
\text { person through negligence) }\end{array}$ \\
\hline & Incapacity & & \\
\hline
\end{tabular}

\section{Discussion}

The charges against Pistorius brought to the court by the State (the prosecution) mobilised the supercrip stereotype to show that he had both intent and capacity to kill, and included charges in addition to that of premeditated murder. By adding the charges of unlawful discharging of a firearm, the prosecution hoped to convince the court that Pistorius was in no way incapacitated by his disability and has a history of risky behaviour, supported by his stereotypical hegemonic masculine behaviour illustrated by his love for 'guns, cars and girls'.

This resonates with Kama's (2004) description of the media portrayal of the supercrip and Murphy's (1990) description of the ways in which men with physical disabilities construct and reconstruct their gender identities to maximise their achievement status, as described by Lorber and Moore (2002). The State Prosecutor followed almost a textbook style of forcing Pistorius to disavow atypical masculinity as described by Gerschick and Miller (2000), and to acknowledge the power and autonomy associated with hegemonic masculinity (Shuttleworth et al, 2012), forcing him into acknowledging intent and capacity to kill.

The defence (for Pistorius), on the other hand, highlighted the 'paradox' of Pistorius as a being both supremely able and significantly disabled, which resonates with Murphy's 
(1990) conceptualisation of the 'embattled identities' of men with physical disabilities. The defence team attempted to subvert the prosecution's claim of hegemonic masculinity by referencing feminine behaviour like falsetto screaming and crying.

The defence argued for not guilty on all charges, based on the claimed vulnerability and incapacity of Pistorius because of his disability, which resonates with what Stadler (2006) noted in the portrayal of people with disabilities as disempowered victims who are in need of help, treatment, or rehabilitation.

The Judge, however, recognised what Stadler (2006) described as the individuality, agency and abilities of persons with disabilities. She recognised the capacities, agency and abilities as well as the vulnerabilities of Pretorius and others in similar situations, but found negligence to reasonably foresee the consequences of his actions.

The Pistorius case shows the intersectionality of gender and disability, as well as the ways in which disability and gender stereotypes are mobilised in the courtroom (intentionally or unintentionally), resulting in the possibility of bias in the process and outcome of a trial, as noted by Pillay (2014).

While this study found that prejudicial assumptions with regard to gender and disability permeated the arguments of counsel on both sides in the trial of Oscar Pistorius, in the final judgment there is no indication that prejudicial assumptions influenced the conviction and sentencing of Pistorius. On the contrary, it was found that the judge was aware of the role of the media in creating possible bias and therefore purposefully subjected evidence that she believed was 'contaminated' by the media by applying objective measures rather than relying on subjective evidence, for example by using expert witnesses, phone records and forensic testing.

In judgment and sentencing, disability rights were upheld by ensuring access to justice through evidence-based fairness and reasonable accommodation of persons with disabilities, including that of sentenced and imprisoned offenders, by ensuring safety and access to health care.

\section{Conclusion}

The gaze on prejudicial assumptions in the courtroom of the selected case provided insight into the influence of pervasive gender and disability stereotypes on public opinion and in the courtroom. As the analyses showed, gender and disability stereotypes can be mobilised in positive and negative ways and in support of opposing arguments.

However, the fact remains that court proceedings and judgments should be free from prejudicial presumptions, as required by South African and international law. The CRPD provides clear standards that can be used as a benchmark for all decisions that may impact persons with disabilities, inside and outside of the courtroom and prisons, and in all policies, programmes and practices in all spheres of society.

The following are recommendations for further research:

- There is a need for further research on 'losing the claim to disability' from a legal and a social perspective. In this study it was noted that some analysts claimed that a 
person with a disability who has achieved success, wealth and security cannot claim vulnerability or special treatment based on their achievement status. This argument invokes the rights protected in Article 13 of the CRPD on the right of access to justice on an equal basis with others.

- There is also a need for further research on the vulnerability of persons with disabilities to crime and victimisation and their right to have their rights protected, especially those pertaining to the right to life, liberty and security of the person (CRPD Articles 10 and 14).

\section{References}

Ashmore RD and Del Boca FK (1981) 'Conceptual approaches to stereotypes and stereotyping', in Cognitive Processes in Stereotyping and Intergroup Behaviour 1, 35.

Braun V and Clarke V (2006) 'Using thematic analysis in psychology', in Qualitative Research in Psychology 3, 77-101.

Currie I and De Waal J (2005) The Bill of Rights Handbook (5th ed.), Wetton: Juta.

Davis R (2014, 7 July) 'Oscar Pistorius and the paradox of the disabled super-athlete', in Daily Maverick, available at: http://www.dailymaverick.co.za/article/2014-07-07oscar-pistorius-and-the-paradox-of-the-disabled-super-athlete/\#.VEtY5vmUcqQ, site accessed October 25, 2014.

Gerschick TJ and Miller AS (2000) 'Coming to terms: Masculinity and physical disability', in TE Ore (ed.) The Social construction of difference and inequality: Race, class, gender and sexuality, London: Mayfield, 125-137.

Gill CJ (2006) 'Disability, constructed vulnerability, and socially conscious palliative care', in Journal of Palliative Care 22, 3, 183-191.

Goffman E (1959) Presentation of self in everyday life, New York: Double Day Anchor Books.

Kama A (2004) 'Supercrips versus the pitiful handicapped: reception of disabling images by disabled audience members', in Communications 29, 4, 447-466.

Lippmann W (1922) Public Opinion, New York: Macmillan.

Lorber J and Moore LJ (2002) Gender and the social construction of illness (2nd ed.), New York: AltaMira Press.

McDougall K (2006) 'A Ag shame' and superheros: Stereotype and the signification of disability', in Watermeyer B, Swartz L, Lorenzo T, Schneider M, Priestly M (eds) Disability and Social Change: A South African Agenda, Cape Town: HSRC Press, 387-400.

Murphy RF (1990) The Body Silent, New York: Norton. 
Nelson TD (2009) Handbook of Prejudice, Stereotyping, and Discrimination, New York: Psychology Press.

Pillay N (2014) 'Equality and Justice in the Courtroom', available at: http://www.ohchr.org/EN/NewsEvents/Pages/DisplayNews.aspx?NewsID=14721\&La ngID=E, site accessed March 5, 2014.

Republic of South Africa (1997) 'Constitution of the Republic of South Africa, No. 108 of 1996', available at: http://www.gov.za/sites/www.gov.za/files/images/a10896.pdf, site accessed April 22, 2015.

Republic of South Africa (2000) 'Promotion of Equality and Prevention of Unfair Discrimination Act 4 of 2000', available at: http://www.pprotect.org/legislation/docs/, site accessed April 22, 2015.

Satz AB (2008) 'Disability, vulnerability, and the limits of antidiscrimination', in Washington Law Review 83, 513.

Shuttleworth R, Wedgewood N and Wilson NJ (2012) 'The dilemma of disabled masculinity', in Men and Masculinities 15, 2.

Silva CF and Howe PD (2012) 'The (in)validity of supercrip representation of paralympian athletes', in Journal of Sport and Social Issues 36, 2, 174-194.

. Smith D (2014) 'SA's very own Greek tragedy', in Mail \& Guardian, October 24$30,16$.

Stadler J (2006) 'Media and disability' in B Watermeyer, L Swartz, T Lorenzo, M Schneider and M Priestly (eds) Disability and social change: A South African Agenda, Cape Town: HSRC Press, 373-386.

The State V Oscar Leonard Carl Pistorius, Case No: CC113-2013. Date: 2014-09-11, 12. Judgment Volume 42, 3280-3351.

United Nations General Assembly, 'Convention on the Rights of Persons with Disabilities: resolution / adopted by the General Assembly, 24 January 2007, A/RES/61/106', available at: http://www.refworld.org/docid/45f973632.html, site accessed November 4, 2014.

Yoder JD (2003) Women and Gender: Transforming Psychology (2nd ed.), Upper Saddle River, NJ: Pearson. 